\title{
Pelješac bridge - design and maintenance
}

\author{
Marjan Pipenbaher \\ Gordana Hrelja Kovačević \\ Tatjana Peteršić \\ Nijaz Mujkanović
}

\author{
Marjan Pipenbaher \\ Ponting Consulting Engineers, Maribor, Slovenia \\ Gordana Hrelja Kovačević, Nijaz Mujkanović \\ University of Zagreb Faculty of Civil Engineering, Zagreb, Croatia \\ Tatjana Peteršić \\ Pipenbaher Consulting Engineers, Slovenska Bistrica, Slovenia \\ Corresponding author: Gordana Hrelja Kovacevic, gordana.hreljađagrad.hr
}

https://doi.org/10.5592/CO/FTCE.2019.10 


\section{Pelješac bridge - design and maintenance}

\section{Abstract}

The Pelješac Bridge is currently the largest bridge under construction in Croatia and in the wider region. The construction began in July 2018 (for the second time), and the bridge should be completed in 36 months. The design work for the bridge started in 2004.Various bridge alternatives were considered during preliminary studies, preliminary design and main design activities. The bridge is located in a high-activity seismic zone with strong winds, and is realised in extremely adverse foundation soil conditions, and in aggressive maritime environment. The multi-span extradosed semi-integral bridge with steel deck was finally chosen for the main design and construction. The history of design, final design and maintenance of the bridge is presented in the paper.

Key words: cable stayed bridge, extradosed bridge, steel box girder, driven steel piles, durability, maintenance

\section{Most Pelješac - projektiranje i održavanje}

\section{Sažetak}

Pelješki most trenutačno je najveći most koji se gradi u Hrvatskoj, ali i u široj regiji. Gradnja mosta započela je u srpnju 2018., po drugi put. Predviđa se da će gradnja trajati 36 mjeseci. Projektiranje mosta započelo je još 2004. godine. Kroz studije, idejna rješenja, idejne projekte i glavne projekte razmatrana su različita rješenja za most. Most je smješten na lokaciji s jakom seizmičkom aktivnošću i jakim vjetrovima. Također, na lokaciji mosta su izrazito nepovoljni uvjeti temeljenja i agresivni uvjeti okoliša. U završnoj fazi projektiranja, za razradu u glavnom projektu i za gradnju odabran je ekstrados most sa čeličnim rasponskim sklopom i poluintegralnom konstrukcijom. $U$ radu je prikazana povijest projektiranja, glavni projekt za odabrano rješenje te preporuke za održavanje mosta.

Ključne riječi: ovješeni most, ekstrados most, čelični rasponski sklop, čelični zabijeni piloti, trajnost, održavanje 


\section{Introduction}

The southern part of Croatia, including the city of Dubrovnik, is currently separated from the rest of Croatia by a small coastal stretch belonging to Bosnia and Herzegovina (Figure I). The idea of fixed road link to connect the whole of Croatia, without having to cross state borders twice, has been studied for more than fifteen years, but has gained a new momentum after Croatia has become an EU member state. The new bridge crossing the sea strait between Croatian mainland and the Pelješac Peninsula shall fulfil this purpose, while also furthering development of the Pelješac Peninsula and nearby islands.
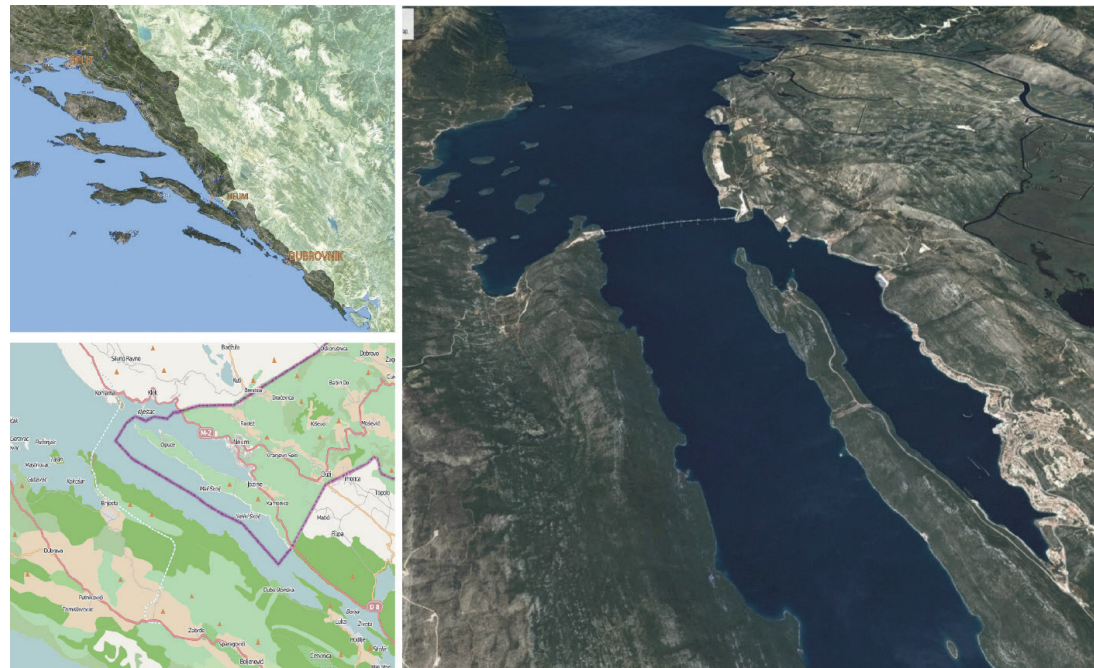

Figure I. Location of Pelješac Bridge

\section{The history of design and construction}

\subsection{Bridge specifics}

The seabed at the bridge alignment is almost level at $-27 \mathrm{~m}$ in elevation, with the stratigraphic pattern of a series of sub-horizontal layers and an irregular top of the rock along the bridge (Figure 2) [I].The foundation soil alongside the planned location is of extremely poor quality, as has been confirmed by detailed geophysical surveys and extensive off-shore investigations, including continuous shear wave survey and geotechnical explorations from a specially equipped drill ship, which included drilling boreholes and sampling in 2004 and 2009 [I].The depth to bedrock is variable along the bridge alignment, ranging from $75 \mathrm{~m}$ to $102 \mathrm{~m}$ in depth in the central portion of the crossing, and amounting to about $39 \mathrm{~m}$ close to the mainland coast. 


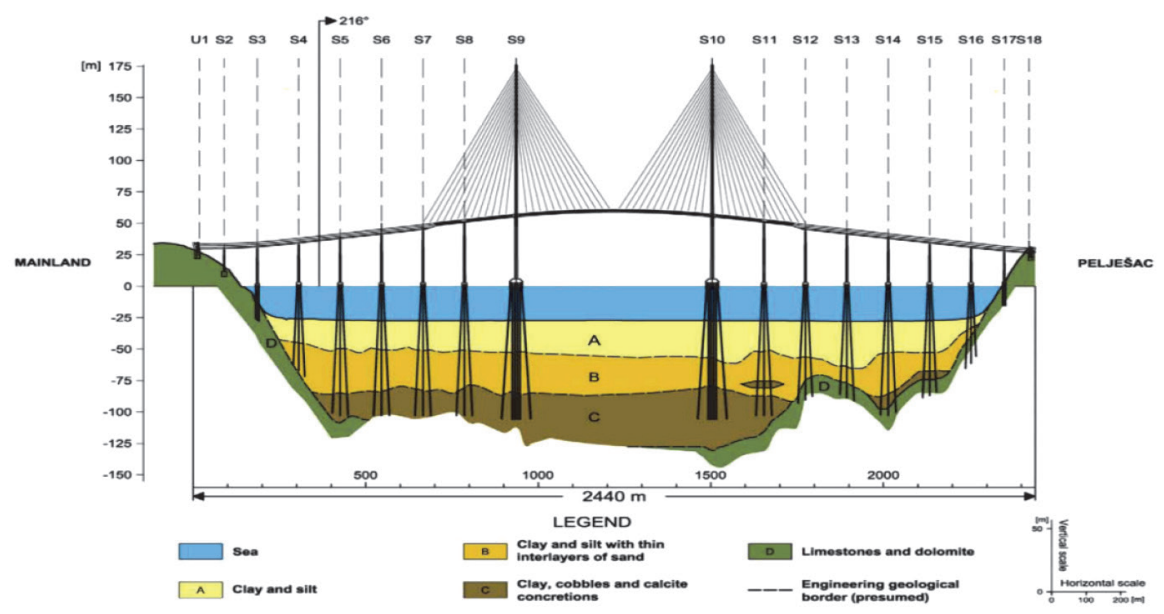

Figure 2. Stratigraphic section at bridge location

The crossing is approximately $2140 \mathrm{~m}$ wide at the sea level and $2380 \mathrm{~m}$ at the gradient line level. The navigation clearance was originally specified as $150 \times 30 \mathrm{~m}$, but had to be changed to a navigation channel at least $200 \mathrm{~m}$ wide with minimum vertical clearance of $55 \mathrm{~m}$ at the specific request of the neighbouring country of Bosnia and Herzegovina, although there is no navigation channel currently chartered in this area and although the Mali Ston Bay is ecologically an extremely sensitive area, where any larger ship traffic might disturb delicate environmental balance of one of the last European natural habitats of oyster mussel and clam farms.

The bridge site lies in a zone of high seismic activity in the vicinity of active seismic faults, where seven significant earthquakes of magnitude $M>6$ occurred in the passed century within $100 \mathrm{~km}$ of the site.

The bridge site is also exposed to high winds with maximum average 10-minute wind speeds of $33,4 \mathrm{~m} / \mathrm{s}$ and wind gust speeds of $47,1 \mathrm{~m} / \mathrm{s}$.

Hence, the key challenges for the bridge design were high bridge alignment lying at approximately $+90,0 \mathrm{~m}$ a.s.l., adverse soil conditions, high seismicity of the site, and stringent environmental requirements.

\subsection{Preliminary studies (2004-2005)}

Because of the above mentioned constraints, it was evident that the total bridge dead weight, and especially the dead weight of the superstructure had to be reduced as much as possible, which was done by adopting a steel superstructure. Also, relatively long spans were utilized to limit the number of expensive foundations. At this stage, the navigation clearance was specified as $150 \times 30 \mathrm{~m}$.

Over 10 bridge types such as girder bridge, truss bridge, arch bridge and cablestayed bridge (Figure 3), were studied at the preliminary stage and, after a detailed evaluation, two alternative solutions were short-listed for the next design phase [2]. 
(1)

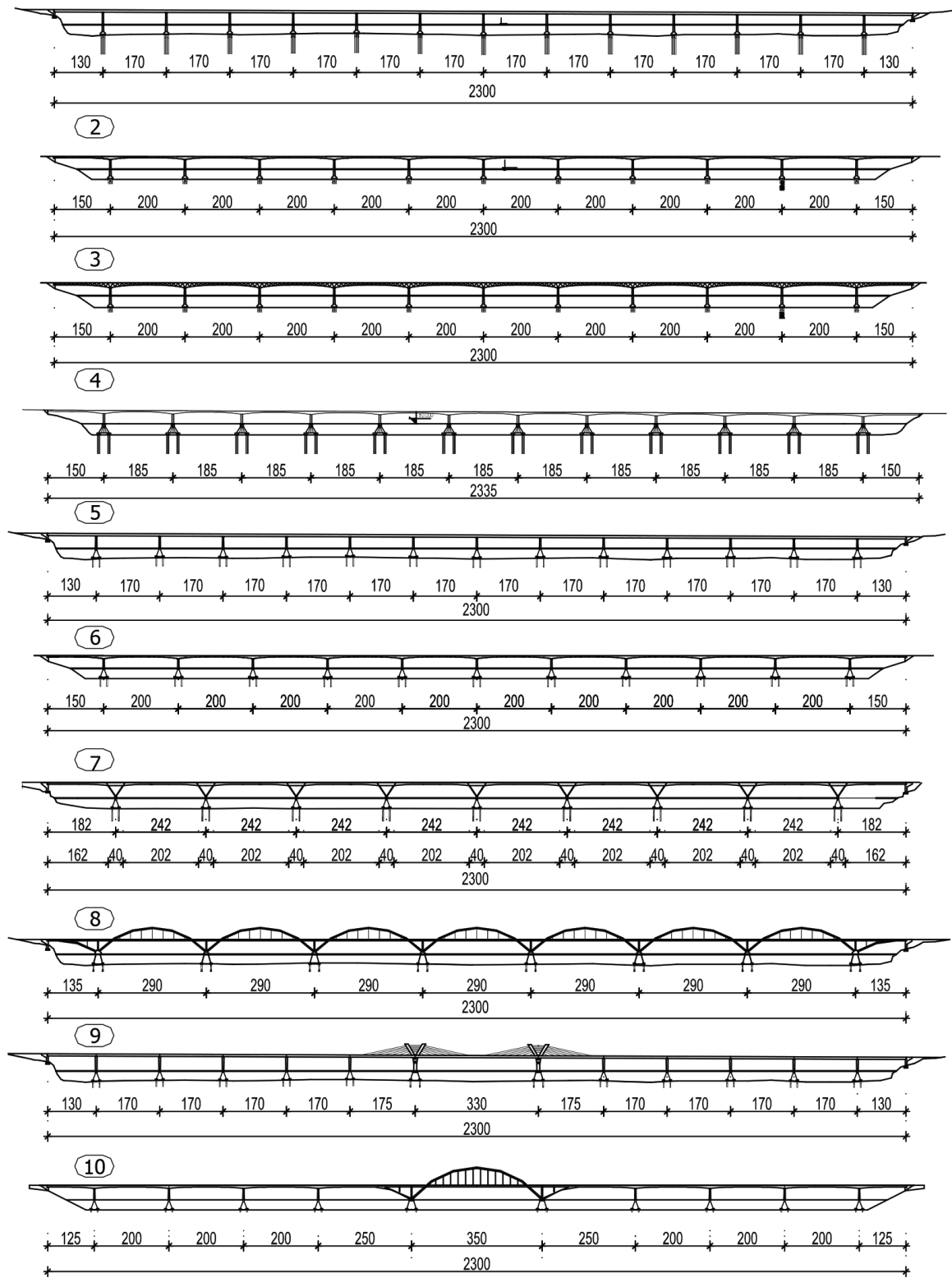

Figure 3. Alternative solutions (2005) 
The choice was based on aesthetical considerations and economic criteria comprising material quantity and complexity of erection technology, but also on predicted future maintenance costs of this large project.

The Committee, appointed by the state of Croatia, finally selected the continuous steel box type superstructure as the most appropriate bridge for the MainlandPelješac Peninsula Crossing, finding this alternative the least imposing on the environment. Therefore, the next stage was the preliminary design for the continuous beam alternative solution.

\subsection{Preliminary design (2005)}

The superstructure was a continuous trapezoidal steel box over 15 spans, with the overall length of $L=94.0+|22.0+| 42 .-0+3 \times|70.0+| 78.0+7 \times|70.0+| 38.0=2,374.0 \mathrm{~m}$ and constant depth of $6.5 \mathrm{~m}$ (Figures 4 and 5) [3].

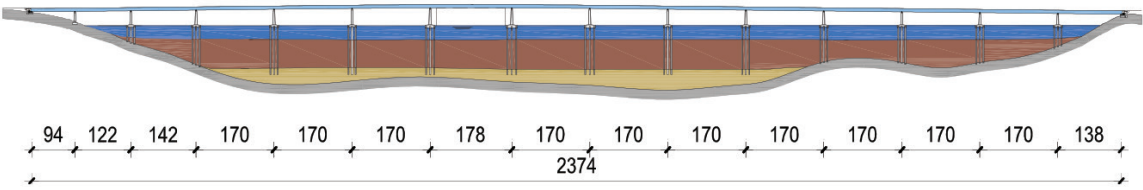

Figure 4. Longitudinal layout of the bridge
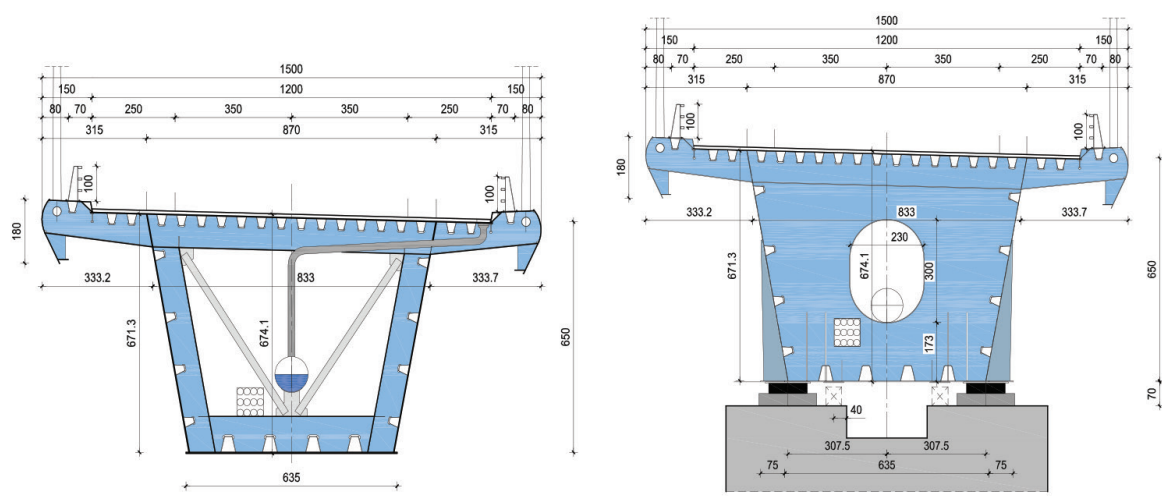

Figure 5. Typical cross sections at midspan and at supports

The total calculated weight of the steel superstructure was $20,000.0$ tons or $556 \mathrm{~kg} /$ $\mathrm{m}^{2}$ of the bridge deck area (using steel grade S355).

All piers in the sea strait were founded on deep foundations, consisting of tubular steel driven piles with the pile cap at the sea level. This turned out to be the most cost-effective solution from the point of view of ease of construction and quantity 
of material used. The pile steel grade was S 355 with the tube thickness varying up to maximum $60.0 \mathrm{~mm}$. The cathodic protection of piles against steel corrosion in an aggressive environment was to be applied.

Reinforced concrete piles were $5.0 \mathrm{~m}$ deep and $20.0 \times 20.0 \mathrm{~m}$ in ground plan.

After the preliminary design was completed and the location permit obtained, new demands on the navigation clearance were defined. The navigation channel was to be at least $200 \mathrm{~m}$ wide with the vertical clearance of $55.0 \mathrm{~m}$. New alternative solutions for the bridge were therefore analysed. All of them were cable stayed bridges and, finally, the cable stayed bridge with the main span of $568 \mathrm{~m}$ and the steel box type superstructure was chosen for the main design.

\subsection{Main design (2009)}

The original main design of the bridge comprising a cable-stayed bridge with the main span of $568 \mathrm{~m}$ and a continuous aerodynamically shaped steel box deck structure (Figure 7), with an overall length of $2404,0 \mathrm{~m}$ (Figure 6) was completed in 2008 [4], [5].

The width of the four-lane roadway was $2 \times 8,0=16,0 \mathrm{~m}$, with two lanes in each direction, separated by a $3,0 \mathrm{~m}$ wide median strip, so that the total width between safety barriers amounted to $20,0 \mathrm{~m}$.

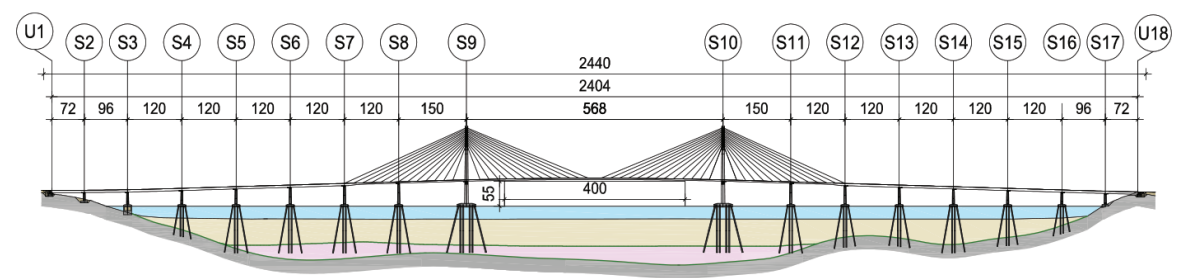

Figure 6. Original bridge design - longitudinal layout

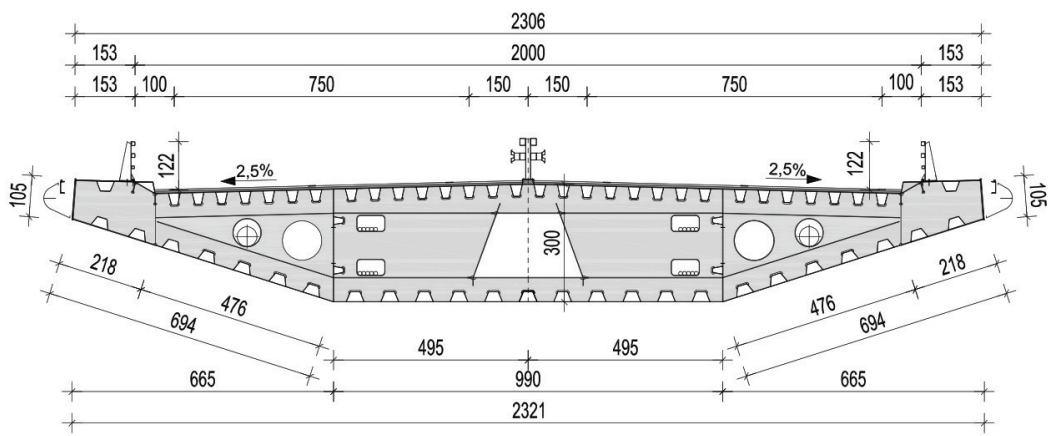

Figure 7. Original bridge design - deck cross-section of main cable-stayed bridge 
The depth of the deck was 3,0 $\mathrm{m}$ for the main cable stayed bridge and 5,0 $\mathrm{m}$ for the approach spans, with a smooth transition between these depths at cable stayed bridge ends. The longitudinal layout of the stay cables was of modified fan type with partial suspension, with cable stays in two inclined planes spaced at $20,0 \mathrm{~m}$ in the longitudinal direction. The streamlined deck cross section was designed to reduce wind action on the bridge and to provide for a high torsional rigidity.

All vertical actions from the deck were to be assumed by structural bearings. Dampers were to be installed on all supports with stiff foundations to mitigate the seismic energy input and minimize structural damage.

Pylons of the cable stayed bridge were designed as diamond shaped pylons with the total height of $176,0 \mathrm{~m}$ above the sea, with the lower parts in concrete, and with only the top 52,0 m parts, where cable stays are anchored, of composite type. All piers were designed with the box type cross section, tapered at both longitudinal and transverse directions.

All piers and pylons in the sea strait were founded on mostly battered driven steel tubular piles. Such foundations turned out to be the most cost-effective solution from the point of view of constructability and amount of materials used.

Design loads adopted for the project are reported in [6]. The nonlinear modal time history analysis, based on superposition of Ritz vectors, but with coupled modal equations, was performed for seismic design. Real earthquake accelerograms for nearby earthquakes (Bar, Ulcinj, Ston) and for the El Centro earthquake, as well as 72 artificial accelerograms, determined by seismic study for the specific bridge location, were analysed. The analysis was carried out taking into account the proposed bridge construction sequence [7].

The total calculated weight of steel for superstructure and piles amounted to $32.000,0$ and 35.000,00 tons, respectively (steel grade S355).

The original main design of the bridge was thoroughly checked by independent certified Croatian and German proof engineers, which was the necessary requirement to obtain the building permit. The bidding process for bridge construction was carried out and the work was awarded to a consortium of Croatian construction companies. The construction of the bridge commenced and abutments and coastal piers on the mainland and the Pelješac Peninsula sides were partially or fully completed. But the investor first slowed down and then finally stopped the bridge construction in 2012 due to the lack of funds.

\subsection{New preliminary designs (2013)}

\subsection{General}

Searching for a more economical bridge solution the investor, Croatian Roads, signed the contract for a new preliminary design with the joint venture composed on the Faculty of Civil Engineering - University of Zagreb \& Ponting/Pipenbaher Consulting Engineers, based on the new terms of reference, this time for a two lane bridge with 
median strip, and with $3.0 \mathrm{~m}$ high wind screens, to be installed on the bridge to ensure that road traffic can run across even in high wind conditions.

Two alternative solutions were proposed, a continuous steel box girder bridge and a multi-span semi integral extradosed bridge with hybrid (predominantly steel) deck. The first alternative was designed by a team from the Structural Department of the Faculty of Civil Engineering - University of Zagreb, and the second alternative was developed by the Ponting/Pipenbaher Consulting Engineers [8].

In both preliminary designs the road alignment adopted in the original design was fully respected. End spans on the mainland side and on the Pelješac Peninsula side $L=96,0+72,0 \mathrm{~m}$, as well as the total bridge length of $2404,0 \mathrm{~m}$, adopted in the original main design, were retained to make use of the already constructed parts of the bridge substructure.

\subsubsection{Continuous steel box girder bridge}

The primary requirement was to design an economical bridge, which also had to be very light so as to take into account high seismic risk in the area. Thus, the bridge deck was designed completely in steel and most of the driven piles, used for bridge foundations in the sea, were designed as slightly battered to minimise horizontal pile-cap dimensions and to increase stiffness of foundation work. The bridge deck was supported on the substructure by bearings (and dampers where necessary) to reduce as much as possible base shear due to seismic action, and not to introduce any bending moments into the bridge deck.

The deck structure was a continuous trapezoidal steel box running over 16 spans, with the overall length of $L=72,0+96,0+\mid 32,0+3 \times 164,0+200,0+256,0+200,0+$ $4 \times 164,0+132,0+96,0+72,0=2404,0$ m (Figure 8).
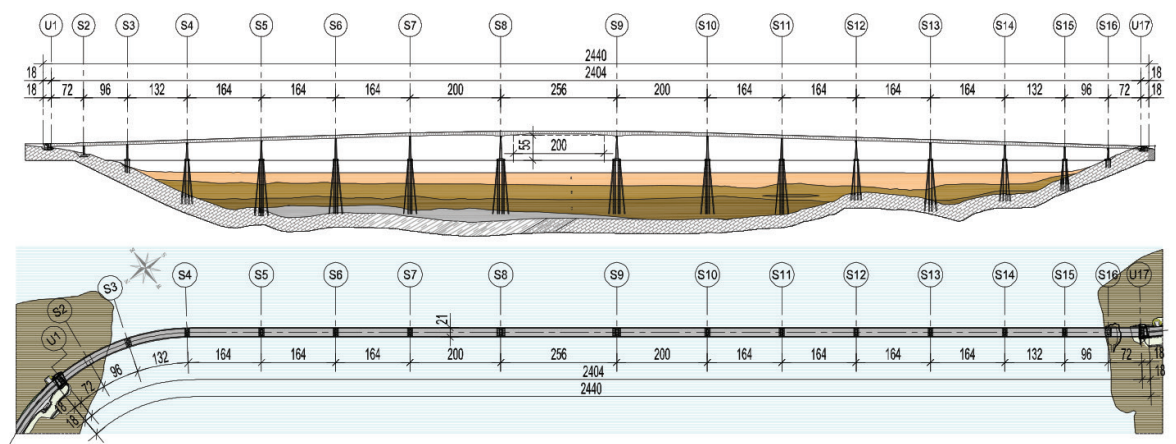

Figure 8. Continuous steel box girder bridge - longitudinal layout and ground plan

The deck structure was a single box type girder of constant depth $\mathrm{d}=6,4 \mathrm{~m}$ (Figure 9), except in the main navigation span and the two neighbouring spans where the box girder depth increased parabolically to the maximum of $10.6 \mathrm{~m}$ above main span piers. 

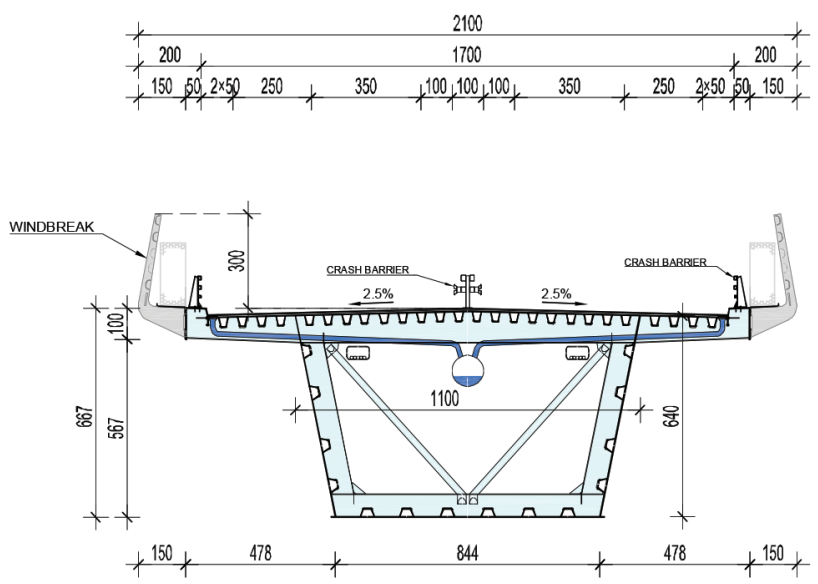

Figure 9. Box girder bridge - typical deck cross-section

The deck plate was cantilevered out symmetrically from both webs and webs were inclined at $78,7^{\circ}$ to the horizontal.

Vertical actions of the steel bridge deck were carried over to the bridge substructure by steel spherical structural bearings, while horizontal actions were transferred by a combination of viscous shock-transmitters and fixed bearings.

All piers were architecturally shaped as box type cross sections with variable outer dimensions, and with heights varying between 19, I m and 49,4 m.

Driven steel piles $2000 \mathrm{~mm}$ in diameter were utilized for pier foundations. A combination of vertical piles and piles battered at $5 \%$ was designed. Battered piled significantly reduce horizontal displacement of pile caps and the whole bridge structure, and assume, by their axial resistance, an important part of horizontal forces due to wind and earthquake action. Piers S4 \& SI2-SI5 were founded on 8 piles connected by a pile cap measuring $11.0 \times 18.0 \mathrm{~m}$ in plan, piers S5-S7 and SI0-SII on 10 piles with a pile cap measuring $12.0 \times 18.0 \mathrm{~m}$ in plan, and piers $\mathrm{S} 8-\mathrm{S} 9$, which support the main navigation span, were founded on 16 piles connected to a pile cap measuring $18.0 \times 18.0 \mathrm{~m}$ in plan. Three-fold corrosion protection of steel piles was planned: additional wall thickness, passive cathodic protection with welded sacrificial anodes, and special paint coatings.

The total steel weight of the superstructure and piles was 25.500,0 and 24.000,00 tons, respectively (steel grade S355).

The rationale for the continuous steel box girder design (Figure 10) was its economy and very small weight, which is very important considering the very high seismicity and adverse geotechnical conditions on the bridge site. Only piers extruding from the sea were architecturally shaped. The idea behind this proven and solid design was that the bridge should blend harmoniously with the environment and not to impose on it. 


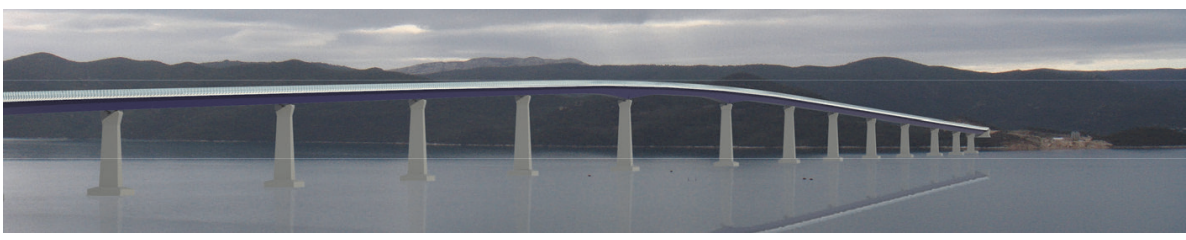

Figure I0. Computer rendering of continuous box girder steel bridge

\subsubsection{Multi-span semi-integral extradosed bridge with hybrid deck}

The multi-span semi-integral extradosed bridge is structurally up-to date, unique in appearance, and resourcefully economical, and thus constitutes a very clear reflection of the present times (Figure II). Such a large and impressive bridge should not be just a high-tech and excellently designed engineering structure without soul and character. Thanks to an inventive approach to the design of this extreme bridge with an integral structure, featuring a hybrid deck suspended on six pylons, the bridge meets crucial design criteria of appearance, stability, durability, usability and economy in construction, which should be favourably reflected in subsequent maintenance costs.

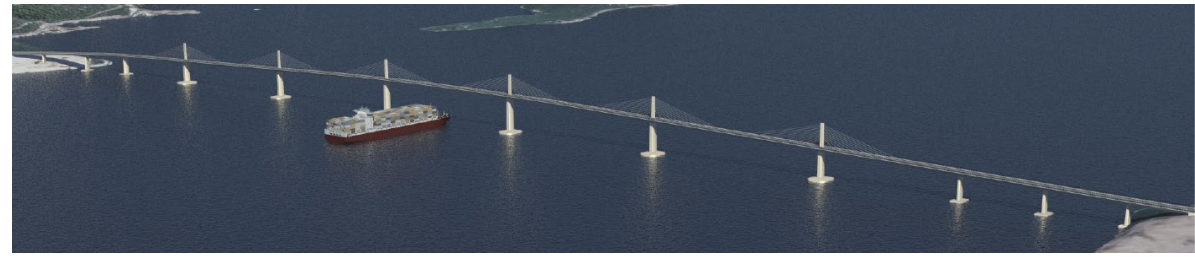

Figure I I. Computer rendering of multi-span semi-integral extradosed bridge aerial view

In their preliminary study, the French consultant SAFEGE preferred the multi-span semi-integral extradosed bridge alternative, stating that it has the following advantages compared to the continuous steel box girder:

- reduced adverse influence on the protected environment of the Mali Ston Bay due to three less piers in the sea,

- reduced construction risks due to three less piers, because foundation construction is technically the most complex and financially the most demanding part of bridge construction,

- reduced number of structural bearings,

- higher level deck intrados in the main navigation span.

Based on these recommendations, the investor selected the multi-span extradosed bridge for further design [9].

After completion of preliminary design, a new environmental study was carried out and the location permit was amended.

The main design of the extradosed bridge [I0] is presented in the next section. 


\section{Multi-span semi-integral extradosed bridge with hybrid deck - main design}

A comprehensive optimisation method was used in the development of structural and architectural concept for this bridge. The central system is a multi-span semiintegral extradosed bridge with six pylons and five $285.0 \mathrm{~m}$ openings, so that a full symmetry in space has been achieved. In the surrounding landscape, the bridge appears as a very light and peaceful composition. An attempt was made to create a bridge that is structurally, technically and technologically advanced, while also being financially optimal and cost effective.

The extradosed cable-stayed deck and centrally placed reinforced concrete pylons, are elastically linked to piers so that in its central part measuring $1832,0 \mathrm{~m} \mathrm{(76 \%}$ of the total bridge length) the bridge is a frame structure without bearings, which provides for additional stability of the bridge in case of seismic and wind action. Bearings and guiders installed on shear keys are designed only at end parts of the bridge - at abutments and piers 2-4 and $\mathrm{II}-\mathrm{I} 3$.

The bridge deck is a continuous hybrid box structure that is suspended in its central part by stays on to six centrally placed reinforced concrete pylons. The steel box deck extends over 12 spans $L=84.0+108.0+108.0+189.5+$ $5 \times 285.0+189.5+108.0+108.0+84.0=2,404.0 \mathrm{~m}$ (Figure 12).

Pylons are $40.0 \mathrm{~m}$ in height so that the pylon height to span ratio is $40.0 / 285.0=0.14$.

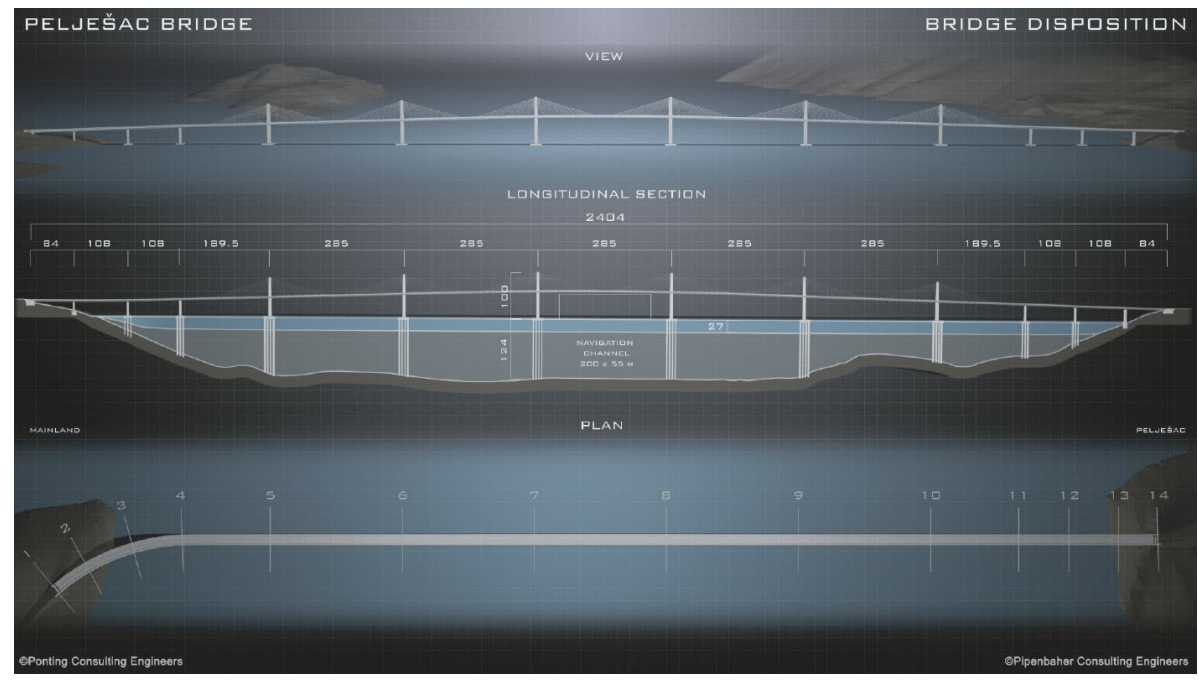

Figure I2. Multi-span semi-integral extradosed bridge - longitudinal layout and ground plan 
Typical superstructure cross-sections at cable stay anchoring of the main cable stayed bridge and at approach spans are shown in Figure 13. The streamlined three cell box deck cross section was designed to reduce wind action on the bridge and to provide for high torsional rigidity. The deck depth is $4.5 \mathrm{~m}$ and the orthotropic deck plate is $22.5 \mathrm{~m}$ in width. All plates, i.e. the deck plate, the bottom plate, inner webs, and inclined bottom plates, are stiffened by longitudinal trough type closed trapezoidal stiffeners.

Transverse frames are spaced at $4.0 \mathrm{~m}$ intervals.

Cable stays are composed of parallel galvanized waxed strands, 0.62 " in diameter in HPDE ducts with outer protrusions to limit potential vibrations due to wind and rain. The number of strands varies from minimum 55 to maximum 109.

Centrally positioned vertical reinforced concrete pylons are elastically linked with the concrete part of the superstructure and are directly connected to piers (Figure 14). They are made of solid concrete grade C70/85 and taper in transverse direction from $5.0 \mathrm{~m}$ at the top to $7 \mathrm{~m}$ at the deck level, while their width is constant in longitudinal direction and amounts to $2.2 \mathrm{~m}$. Stay-cables are anchored in pylons via ten deviators.

Piers of supports S5 - SI0 represent the bottom part of the pylons (Figure 14). They are elastically fixed to the massive pile caps at the bottom, and to the superstructure and pylons at the top.

The height of piers varies from 37.927 to $53.35 \mathrm{~m}$.

The piers feature a hollow box cross section with rounded corners. The outer dimensions at the bottom and top of tallest piers are $7.0 \mathrm{~m} \times 11.0 \mathrm{~m}$ and $7.0 \times 8.1$ $\mathrm{m}$, respectively. The wall thickness of piers is $0.70 \mathrm{~m}$ for walls perpendicular to bridge axis, and $0.80 \mathrm{~m}$ for walls in the direction of bridge axis.

At piers S7 and S8 located in the navigation channel, the wall thickness at bottom part of the piers, in the length of II $.35 \mathrm{~m}$, was increased to $1.20 \mathrm{~m}$ in both directions. Therefore, the piers can withstand local ship collision forces.

Relatively short piers S2-S4 and SII-SI3 (19.2 - 3I.78 $\mathrm{m}$ in height) also feature a hollow box cross section with rounded corners (Figure I5). The outer dimensions at the bottom and top are $4.25 \mathrm{~m} \times 8.0 \mathrm{~m}$ (tallest pier) and $4.25 \times 10.0 \mathrm{~m}$, respectively. The wall thickness of all piers is $0.60 \mathrm{~m}$ in both directions and is invariable. 

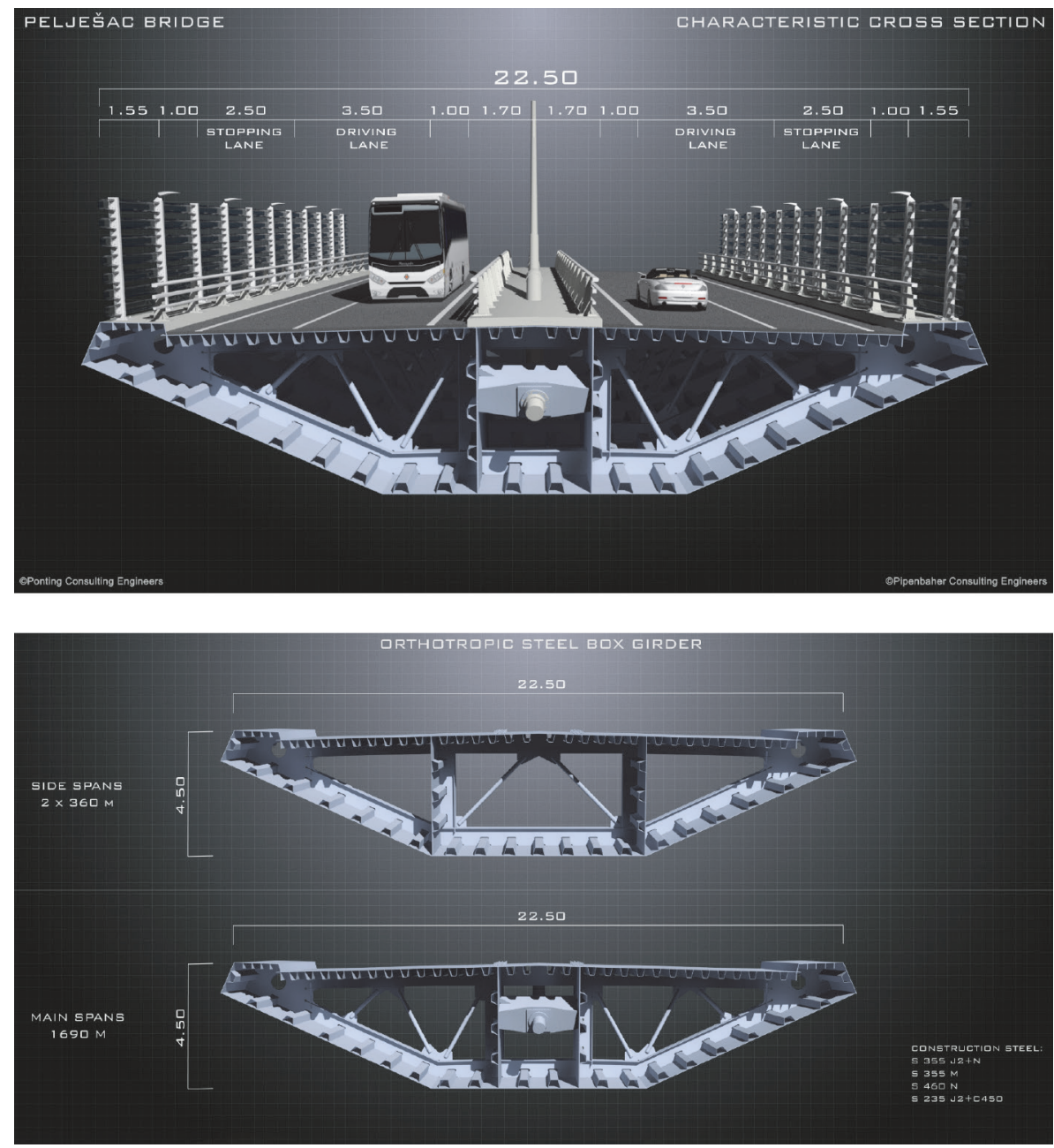

Figure I 3. Multi-span semi-integral extradosed bridge - deck cross-sections

At the top of the piers, enough space is provided for installation of large bearing pads and side guiders / bearings. Also, an appropriate space is provided for positioning the bearing replacement jacks, and for the opening enabling access to piers (inspection and maintenance of bearings).

According to the design, all piers $\mathrm{S} 2$ - SI 3 will be fabricated using concrete grade C50/60.

Abutments $\mathrm{UI}, \mathrm{UI} 4$ and piers $\mathrm{S} 2, \mathrm{SI} 3$ are founded into the compact rock base.

Piers S3 - SI2, situated in the sea strait, are founded onto driven steel piles measuring 
1800 and $2000 \mathrm{~mm}$ in diameter. The length of piles varies from 36 to $128.6 \mathrm{~m}$. At the sea level, the piles are fixed to the massive concrete pile cap.

Piles at supports S3, S4, SIO - SI 2 are filled with concrete in full length and feature an additional concrete socket to enable load transfer into the solid rock base.

The foundation work for pylons S5 - SI0 is realized with a group of 18 / 20 piles, $2000 \mathrm{~mm}$ in diameter, fixed to the RC pile cap at the sea level. Rectangular pile cap dimensions are $29 \mathrm{~m}$ (transverse to the bridge axis) and $23 \mathrm{~m}$ (along the bridge axis). The thickness of the cap varies from 4.0 (at the edge) to $5.0 \mathrm{~m}$ (in the pier area). The length of piles is up to $128.6 \mathrm{~m}$.

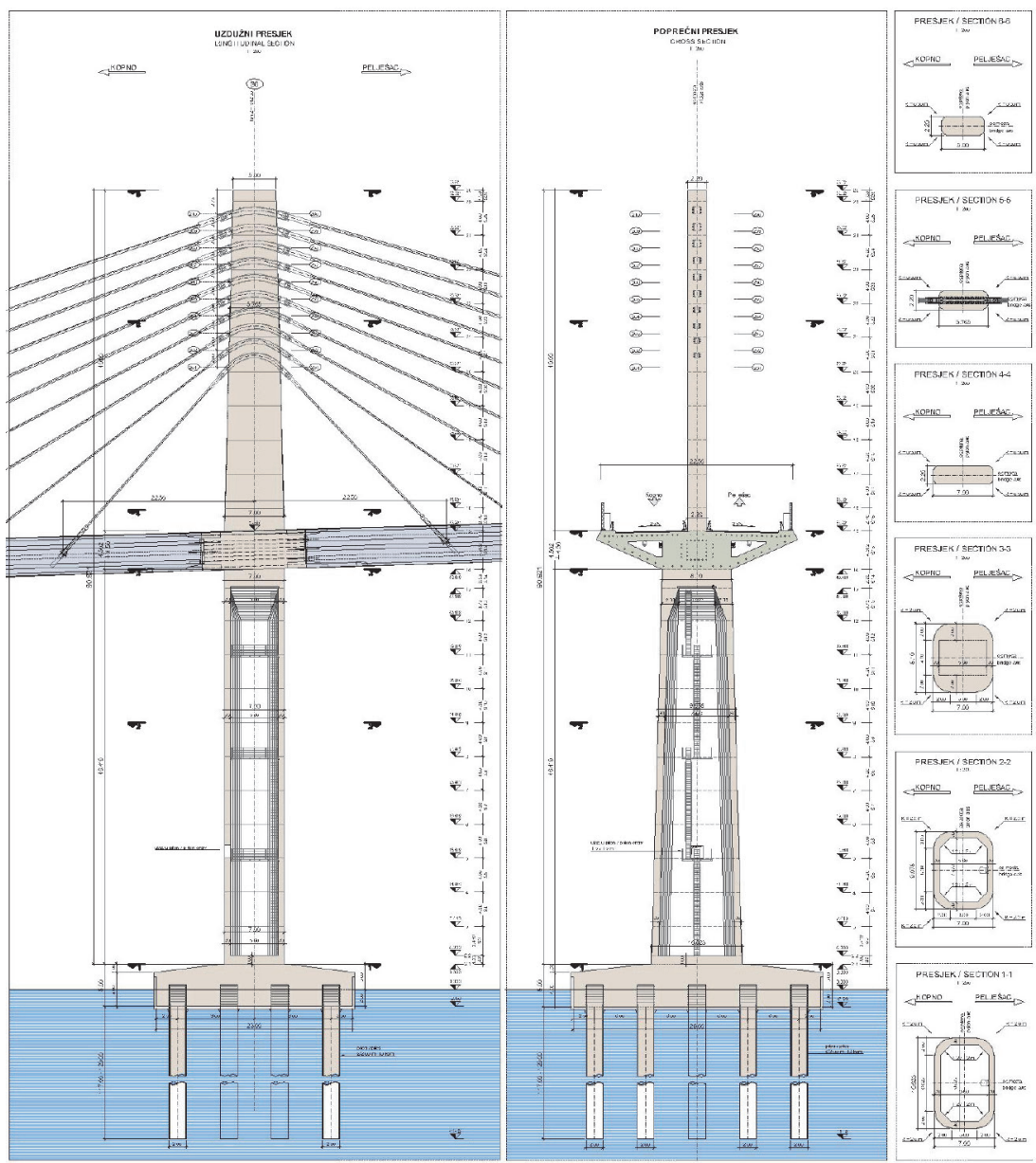

Figure I4. Pylon S6 
Steel piles measure $2000 \mathrm{~mm}$ in outer diameter and $40 \mathrm{~mm}$ in wall thickness. The pile driving shoe measuring $2000 \mathrm{~mm}$ in length and $60 \mathrm{~mm}$ in thickness is foreseen at the bottom of the pile (higher steel quality of S460 was adopted). At piers S5 - S9, top pile parts in the length of $40 \mathrm{~m}$ are filled with reinforced concrete to increase their stiffness.

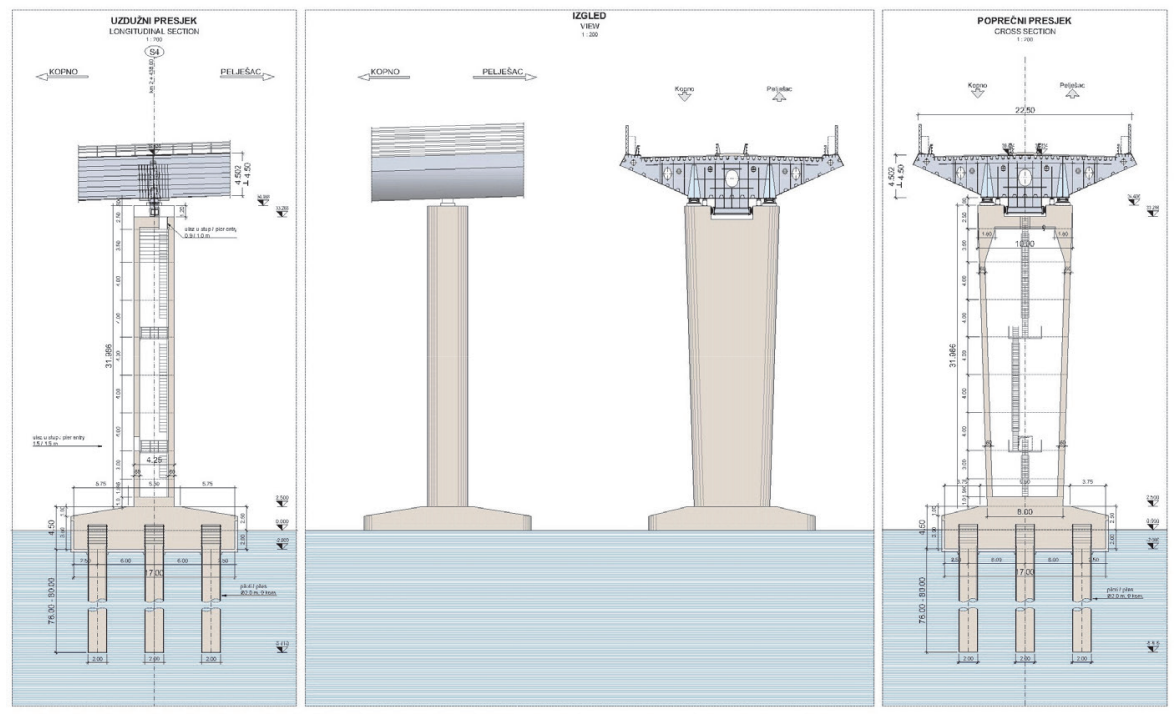

Figure 15. Pier S4

As mentioned earlier, the piers S5 to SIO are fixed to the concrete part of the superstructure, so that the total horizontal force in longitudinal direction will be assumed by these six piers. Longitudinal movable bearings that assume vertical force only are placed at all other piers and at both abutments. At these piers, horizontal force in transverse direction is assumed by side bearings (guiders).

Static and dynamic bridge analysis was performed using several software packages RM-BRIDGE Enterprise - Bentley, SOFISTIK, Midas Civil, ANSYS, Plaxis 3D-VIP, OpenFoam, SolidWorks. To enable the PCE IQC - Internal Quality Control, two totally independent static and dynamic analyses were performed using the software RM-BRIDGE / Bentley and SOFISTIK AG, for construction and service life of the structure.

Significant non-linear behaviour in soil, and inelastic deformation in foundation elements, are expected as the structure is founded on very long and slender piles passing through layers of soft soil.

For accurate static and dynamic analyses, it was important to reliably derive nonlinear inelastic soil springs and to validate the model with linear soil springs used in the bridge response spectrum analyses. For this purpose, a 3D continuum model of the soil foundation system was created for a typical support (Support 9). 
A site-specific engineering seismological study, based on the seismic source zone characterization and attenuation relationships for the south of Croatia, was undertaken by the Croatian Seismological Service. The bridge site lies in a zone of large seismicity in the vicinity of active seismic faults, where seven significant earthquakes of magnitude $M>6$ occurred in the past century within $100 \mathrm{~km}$ of the site. The maximum magnitude was estimated at $M_{\max }=6.5$ and the maximum seismic intensity at $\operatorname{Imax}=9.2^{\circ} \mathrm{MCS}$. Seventy-two artificial simulated accelerograms for earthquake magnitudes of $M=$ 6.0, 6.5, 7.0, and 7.5 were defined in this report for epicentral distances of $5,10,25$, 50,100 , and $150 \mathrm{~km}$. The epicentres were always assumed to be at the depth of $10 \mathrm{~km}$ from the surface, and the records were produced for the level of basic sound rock. Nonlinear time history analyses were performed using a computer model with nonlinear springs.

Nonlinear $(\mathrm{p}-\mathrm{y})$ springs were defined for horizontal direction, and nonlinear springs for skin friction were defined for vertical direction.

The detailed analysis of superstructure and pylons was performed with shell, solid, and 3D finite elements.

In addition, the wind barrier efficiency analysis also included the CFD (Computational Fluid Dynamic) wind analysis.

The total weight of steel was 34,727.0 and 31,000.00 tons for superstructure and piles, respectively.

The wind tunnel testing was performed, both on the section model and full bridge model.

The main design of the bridge was thoroughly checked by independent certified proof engineers. After completion of the main design, a new amendment to the construction permit was obtained (2017).

The bidding process for bridge construction was conducted and, in July 2018, the bridge construction contract was signed between the investor Croatian Roads and the joint venture: China Road and Bridge Corporation, CCCC Highway Consultants Co. Ltd., China, CCCC Second Harbour Engineering Co. Ltd., China, CCC Second Highway Engineering Co. Ltd., China.

\section{Bridge construction}

The bridge construction started in July 2018. First, tubular steel piles were driven by a hydraulic hammer operated from a large derrick barge, utilizing the latest offshore technology.The excavation of soil from the piles and pile concreting work is currently in progress.

Pile caps consist of precast shells and concrete cast in situ. Precast shells shall be cast at a convenient location on the coast, equipped with lift chambers, and floated to the final position above the piles. After centring of the shell on steel piles, openings will be sealed and the pile cap will be completed with in situ concrete.

Concrete box type piers and pylons shall be constructed using the climbing formwork. 
The steel superstructure of approach spans and two side spans of the cable stayed bridge shall be joined into span-long segments at a convenient location on the coast. These segments will be transported to the site one by one on two derrick barges, lifted into position, and connected to the previously erected base segment on top of the piers. The weight of a typical $104.0 \mathrm{~m}$ long segment is approximately I,600.0 tons. The main cable stayed bridge spans shall be erected using the cantilever method, with typical segments measuring $20 \mathrm{~m}$ in length. The construction will progress from all six pylons at the same time.

All construction phases have to be realised very carefully due to stringent ecological requirements.

The bridge will be finished in 36 months.

\section{Durability and maintenance}

\subsection{Overview}

Because of immense importance of this bridge, solutions that contribute to greater durability have been adopted in all stages of the design process. Specified materials and products for the bridge are all of highest quality. The design specifications require that the bridge construction must be carried out with utmost care, so that maximum durability can be achieved.

\subsection{Measures for increasing durability}

The measures that should ensure the maximum design durability, as based on applicable standards, are specified in design criteria formulated in the main design

[II].These measures are:

- The design working life category, according to EN 1990,Section 2.3, is 5. Recognizing that an extended service life can more economically be achieved with proper measures taken during design and construction, than with later rehabilitation, the bridge is designed for a 100-year service life before major maintenance of nonreplaceable components is needed. Components that can be replaced without significant disruptions to bridge use are designed for a lower service life.

- Required reliability relating to structural safety and serviceability will be achieved by suitable combination of measures relating to design and measures relating to quality assurance and control, according to EN 1990, Annex B; the reliability set for the Pelješac Bridge is high.

- Consequence class is CC3.

- Reliability class is RC3.

- Design supervision level is prescribed as DSL3.

- Inspection level is prescribed as IL3.

- Execution class is prescribed as CC3. 
- Service category for steel parts (according to HRN EN 1090-2, Table B.I) is SC2.

- Execution class for steel parts (according to HRN EN 1090-2, Table B.3) is prescribed as EXC4.

An increased bridge durability is ensured through structural shaping of the details and appropriate additional measures. In this respect, the following measures are applied:

- All concrete elements are shaped in such way that there are no sharp edges. Pile cap and pier edges are rounded with a minimal radius of $50 \mathrm{~cm}$.

- High quality concrete with proper concrete mixture ensuring high resistance to water and chloride penetration is prescribed.

- The thickness of concrete cover on pile caps is increased to $85 \mathrm{~mm}$, and on piers and pylons to $75 \mathrm{~mm}$.

- Concrete cover is additionally reinforced with stainless steel bars. The bar diameters are 14 to $16 \mathrm{~mm}$ ensuring cracks lower than $0.2 \mathrm{~mm}$.

- Concrete surfaces will be additionally protected with protection coating. Inhibitors will thus penetrate deep into the concrete mass.

- Special attention is given to casting massive concrete elements (pile caps). A cooling system will be installed to provide for the temperature difference of less than $25^{\circ} \mathrm{C}$.

- High quality and high durability corrosion protection is designed for the steel structure.

- Cathodic protection shall be installed on steel piles and pile caps.

- High-quality EU certificated equipment will be installed on the bridge.

- Preliminary testing of materials and bearing structural elements (stay-cables) are prescribed.

- The sacrificial wall on the shore is to be concreted under the same conditions as the bridge elements, and thereafter the destructive tests can be carried out to monitor the condition of concrete on the most exposed elements of the bridge.

These measures are implemented in the scope of quality control and in subsequent design phases, and also at the bridge construction stage, by adopting and implementing high standards of construction and construction supervision.

\subsection{Concept of bridge management, monitoring and maintenance system}

\subsubsection{Overview}

The "Concept of bridge management, monitoring and maintenance" (Concept) [II], which was a part of tender documentation, is the basis for preparing the "User Manual, Monitoring and Maintenance of the Pelješac Bridge", which shall be completed together with the as built design, and for preparing the detailed bridge-monitoring design to be completed together with the detailed design of the bridge. 
The Concept provides guidelines for the monitoring, inspection, testing, data processing, and regular maintenance of the bridge. It also describes and clarifies basic features of the bridge, necessary for planning repairs, as well as basic assumptions for bridge analysis, in order to help in the design of major interventions, if necessary. The assessment of degradation and damage of the bridge elements is of crucial importance for the maintenance of the bridge in use, and it is based on monitoring, inspection, testing and expertise.

The most important factor are estimates given on the basis of continuous monitoring and regular inspections, which may result in the conduct of detailed inspections, repairs, and maintenance works.

Although damage is not foreseeable, the Concept defines the places where it may occur, or where it can greatly affect the safety of the bridge structure or its users.

\subsubsection{Bridge monitoring}

Continuous structural monitoring during construction and use of the bridge enables:

- analysis of short and long-term structural behaviour

- early identification of potential damage

- effective planning of maintenance work

- assessment of the remaining serviceability

- increased safety and reliability.

Surveillance will be carried out with the following devices to be installed on the bridge:

- GPS devices

- accelerometers

- measuring devices based on optical fibres

- anemometers

- meteorological station

- seismographs.

The monitoring system provides for the continuous monitoring of structural and non-structural elements of the bridge, and continuous measurement of the following features:

- number and composition of vehicles in traffic

- deformations of main bridge elements

- dynamic behaviour of structure (vibration, acceleration)

- specific deformations and stresses in main bearing structural elements of the bridge

- fatigue of steel structures, prestressed cables, and stays

- air temperature and temperature of structural elements

- humidity

- wind velocity and direction

- seismic activity of the surrounding area 
- corrosion and decay of concrete

- corrosion of reinforcement

- condition and forces of stays.

\subsubsection{Bridge inspection and maintenance}

Regular and exceptional inspections are foreseen during the useful life of the bridge. The following inspection guidelines are provided in the Concept:

- regular daily inspection in the scope of regular road inspections

- seasonal inspections (twice a year)

- annual inspections

- main inspection checks (every 2 / 4 years)

- exceptional inspections (after earthquake, stormy winds, fire, ship impact, other accidents on the bridge, etc.)

It should be noted that main inspections (and exceptional inspections, if needed) also include appropriate bridge testing.

The damage and deficiency estimation will be made based on the results of the above-mentioned inspections and tests.

Bridge maintenance is a set of all measures and procedures to be undertaken during the lifetime of the structure to achieve the desired durability, i.e. during the lifetime of the bridge the required level of safety and usability should always be respected.

Maintenance activities are conducted:

- Continuously (cleaning of bridge surface, drainage, bearings, expansion joints, etc.)

- Periodically (corrosion protection, reconditioning of pavement layers, etc.)

- If necessary (repair of mechanical damage, replacement of obsolete parts, etc.)

Documents relating to each maintenance operation must properly be filed so as to enable analysis of the results and, hence, estimation of the integrity and remaining service life of the bridge.

Maintenance guidelines are given in the Concept.

\section{Conclusion}

The construction work on the Mainland - Pelješac Peninsula Bridge, the vital fixed road link for connecting all parts of Croatia, is currently in progress. The bridge is scheduled fro completion in July 2021.

Numerous solutions have been prepared during the long journey of design development (as is appropriate for such bridge). In the end, the solution of the extradosed bridge was chosen based on feasibility study results.

Solutions contributing to bridge durability were adopted in the design. Guidelines given for the monitoring and maintenance of the bridge will greatly contribute to the successful maintenance of the bridge. 


\section{References}

[I] Bolanča, K., Bolfan, L., Soldo, M.: Mainland-Pelješac Bridge Geotechnical Report, Foundations S4-SI6, Institut IGH, Zagreb, 201 I (in Croatian)

[2] Radić, J., Šavor, Z., Hrelja, G., Mujkanović, N., Gukov, I., Vlašić, A., Mandić, A., Kindij, A.: Overview of Pelješac Bridge Design, SECON Conference on Bridges, Cavtat, Dubrovnik-Neretva County, Croatia, pp. 67-84, 2006.

[3] Šavor, Z., Radić, J., Preliminary Designs of Mainland-Pelješac Peninsula Bridge, Structural Department, Faculty of Civil Engineering, Zagreb, 2005 (in Croatian).

[4] Šavor, Z., Radić, J.: Main Design of the Pelješac Bridge, Structural Department of the Faculty of Civil Engineering, University of Zagreb, 2008 (in Croatian).

[5] Hrelja, G., Radić, J., Šavor, Z.:Analysis and Design of Pelješac Bridge in Croatia, 33rd IABSE Symposium on Sustainable Infrastructure, Bangkok, Thailand, pp. I I 2-I I 3, 2009.

[6] Šavor, Z., Hrelja, G., Mujkanović, N., Vlašić, A.: Design Loads for Pelješac Bridge, Joint IABSE-fib Conference on Codes in Structural Engineering, Cavtat, Dubrovnik-Neretva County, Croatia, Pp. $48 I-488,2010$.

[7] Šavor, Z., Radić, J., Hrelja G., Lazarević D., Atalić, J.: Seismic Design of Pelješac Bridge, Croatia, Bridge Structures, 5,(2009) 2-3, pp. 97-108.

[8] Radić, J., Šavor, Z., Pipenbaher M.: New Preliminary Designs of the Pelješac Bridge, Joint Venture Faculty of Civil Engineering, University of Zagreb \& Ponting/Pipenbaher Consulting Engineers, 20I3 (in Croatian).

[9] Radić J., Šavor, Z., Pipenbaher, M., Hrelja Kovačević, G.: New Alternative Solutions for Pelješac Bridge in Croatia, IABSE Symposium Engineering for Progress, Nature and People, Madrid, pp. 5I 8-5 I9, 2014.

[10] Pipenbaher, M.: Main Design of the Pelješac Bridge, Joint Venture Faculty of Civil Engineering, University of Zagreb \& Ponting/Pipenbaher Consulting Engineers, 2016 (in Croatian).

[II] Pipenbaher, M.: Concept of bridge management, monitoring and maintenance, Joint Venture Faculty of Civil Engineering, University of Zagreb \& Ponting/Pipenbaher Consulting Engineers, 2016 (in Croatian). 